\title{
Parameters of Soybean Cultivated in Succession With Intercropping System of Out-of-Season Corn With Green Manure
}

\author{
Geovani Genovesi \\ Department of Agronomy, University Center of Maringá - UNICESUMAR \\ Avenue Guedner, nº 1610, Jardim Aclimação, CEP: 87050-390, Maringá, Paraná, Brazil \\ Tel: +55-43-99935-8990Ｅ-mail: geovanigenovesi@ hotmail.com
}

\begin{abstract}
Giuliano Patrick Rasera
Master Program in Science, Technology and Food Safety, University Center of Maringá - UNICESUMAR

Avenue Guedner, nº 1610, Jardim Aclimação, CEP: 87050-390, Maringá, Paraná, Brazil Tel: +55-44-99889-9334Ｅ-mail: giurasera@hotmail.com
\end{abstract}

\begin{abstract}
Humberto Misdei Moreski
Department of Agronomy, State Universit of Maringá - UEM

Avenue Colombo, 5790, Jardim Universitário, CEP 87020-900 - Maringá, Paraná, Brazil

Tel: +55-44-98831-6458Ｅ-mail: humberto.moreski@ unicesumar.edu.br
\end{abstract}

Daniele Fernanda Felipe

Master Program in Science, Technology and Food Safety, University Center of Maringá - UNICESUMAR

Avenue Guedner, n 1610, Jardim Aclimação, CEP: 87050-390, Maringá, Paraná, Brazil Tel: +55-44-99953-5123 E-mail: daniele.felipe@uol.com.br

André Ribeiro da Costa

Master Program in Science, Technology and Food Safety, University Center of Maringá 


\section{- UNICESUMAR}

Avenue Guedner, n 1610, Jardim Aclimação, CEP: 87050-390, Maringá, Paraná, Brazil Tel: +55-44-99801-2700Ｅ-mail: rcosta4@ hotmail.com

\section{Ricardo Andreola}

Master Program in Science, Technology and Food Safety, University Center of Maringá - UNICESUMAR

Avenue Guedner, n 1610, Jardim Aclimação, CEP: 87050-390, Maringá, Paraná, Brazil Tel: +55-44-99129-9964Ｅ-mail: randreola25@uol.com.br

Aline Maria Orbolato Gonçalves-Zuliani

Department of Agronomy, University Center of Maringá - UNICESUMAR Avenue Guedner, n 1610, Jardim Aclimação, CEP: 87050-390, Maringá, Paraná, Brazil Tel: +55-44-99918-4124Ｅ-mail: alineorb@ hotmail.com

\section{Graciene de Souza Bido}

Master Program in Science, Technology and Food Safety, University Center of Maringá - UNICESUMAR

Avenue Guedner, nº 1610, Jardim Aclimação, CEP: 87050-390, Maringá, Paraná, Brazil Tel: +55-44-99916-1664Ｅ-mail: gsbido@hotmail.com

Anny Rosi Mannigel (Corresponding author)

Master Program in Science, Technology and Food Safety, University Center of Maringá - UNICESUMAR

Avenue Guedner, nº 1610, Jardim Aclimação, CEP: 87050-390, Maringá, Paraná, Brazil Tel: +55-44-99116-9085Ｅ-mail: armannigel@gmail.com

Received: Sep. 6, 2019

doi:10.5296/jas.v7i4.15404
Accepted: Oct. 8, 2019

Published: Oct. 11, 2019

URL: https://doi.org/10.5296/jas.v7i4.15404 


\section{Abstract}

Most Brazilian soils have low organic matter content, and the current management systems used in agriculture contribute to worsening this situation. The introduction of practices that lead to the increase of soil organic matter becomes more necessary for agrosystems to be sustainable, ensuring high yields because only then the production chain becomes profitable and enables agricultural production. The present work aimed to investigate the effect of intercropping practices among corn crop with different green manures in soybean agronomic parameters. The work consisted of five treatments using Brachiaria ruziziensis (Brachiaria); Raphanus sativus (Forage Turnip); Crotalaria spectabilis cv. Common (Crotalaria); Avena strigosa (Black Oats); and a control area (single maize) with five replications. Different aspects related to successor cultivation with soybean were evaluated taking into consideration agronomic aspects such as stem thickness, number of pods, plant height, the weight of one thousand grains and yield per hectare presented by the crop. The work demonstrated that brachiaria green manure in consortium with out-of-season corn crop promoted the highest plant height and number of pods for the soybean crop in succession.

Keywords: crop management, glycine max, Zea mays

\section{Introduction}

Intercropping systems are the cultivation of different plant species in the same period and area (Souza and Macedo, 2007). The benefits of intercropping maize with green manures are: increased dry matter production, higher soil cover when crop is grown, greater efficiency and speed in recycling and nutrient availability due to the exploitation of different soil volume by root systems with different patterns and in the permanence of cultural residues on the soil for a more extended period of time (Alvarenga et al., 1995, Rodrigues et al., 2012).

According to Dall'Agnol et al. (2010), when related to world agribusiness, soybean is among the economic activities that present the most significant growth in the last decades. This factor responds for several aspects, including the construction of an important international market supported by trade in soy products and the establishment of soy as a relevant source of vegetable protein, mainly because it attends the growing demand of the areas related to the production of animal origin, and greater elaboration and supply of technologies, which enabled the expansion of soy production to various regions of the world.

The objective of this work was to evaluate the effect of corn intercropping with different green manures on soybean agronomic parameters in succession crop.

\section{Material and Methods}

\subsection{Study Area}

The experiment was carried out at Fazenda Bela Vista, located in Cambira-Paraná (PR), Brazil, Latitude $-23^{\circ} 34$ '58 " Longitude $-51^{\circ} 34$ ' 42 ". The experimental work was carried out from the beginning of March of 2016 and was conducted until March 2017. 


\subsection{Treatments}

The experimental unit consisted of a total area of $450 \mathrm{~m}^{2}$ subdivided into plots of $5 \times 3.6 \mathrm{~m}^{2}$, where out-of-season corn crop was cultivated intercropped with four other species, which were: T 1 - Brachiaria ruziziensis (brachiaria); T 2 - Raphanus sativus L (Forage Turnip); T 3 - Crotalaria spectabilis cv. Common (Crotalaria) T 4 -; Avena strigosa (Black Oats); and an area of T 5 - control (single corn). The population of maize had 5.6 plants per linear meter, its row spacing was $90 \mathrm{~cm}$, using a base fertilizer $186 \mathrm{~kg} \mathrm{ha}^{-1}$ of the formulated $10-15-15$ $\left(10 \% \mathrm{~N} ; 15 \% \mathrm{P}_{2} \mathrm{O}_{5} ; 15 \% \mathrm{~K}_{2} \mathrm{O}\right)$. In the row spacings crops used in the consortium were sown. They belonged to grass and legume families.

Out-of-season corn was planted on March 14, 2016, on the soybean remains, and the species used as green manure were sown on the same day and $10 \mathrm{~kg} \mathrm{ha}^{-1}$ was used for all green manures.

\subsection{Evaluations Performed}

The dry mass of the species used as green manure was evaluated, then picked using a collecting a frame of $1 \mathrm{~m}^{2}$ for each repetition. The moisture found in the species was eliminated employing a forced air circulation oven.

The other evaluations performed were: plant height $(\mathrm{cm})$; the number of pods and stem thickness. They were carried out only once at the end of the crop cycle when four different plants were randomly chosen within each repetition. In the evaluation that includes productivity, two methodologies were adopted. For corn, two central lines were harvested, which comprised $1 \mathrm{~m}^{2}$, stipulating the result in $\mathrm{kg}$ per hectare. For soybean yield, it was used 1 meter wide by 2 meters long and the result was also stipulated in $\mathrm{kg}$ per hectare.

The results were statistically compared using the Tukey test, with a significance level of 5\% through the statistical program SISVAR (Ferreira, 2014).

\section{Results and Discussion}

Figure 1 shows the dry matter yield of green manure shoot in kilograms per hectare. Despite the water deficit conditions and low temperatures that occurred during this experiment, the brachiaria showed great ability to grow and develop as it was also observed in work by Batista et al. (2011). The brachiaria provided much higher dry mass production in relation to the other species studied by presenting characteristics of rusticity and aggressiveness (Garcia et al., 2013), in addition to showing an excellent adaptation to low fertility soils and prompt establishment providing excellent soil vegetation coverage (Oliveira et al., 2001). 


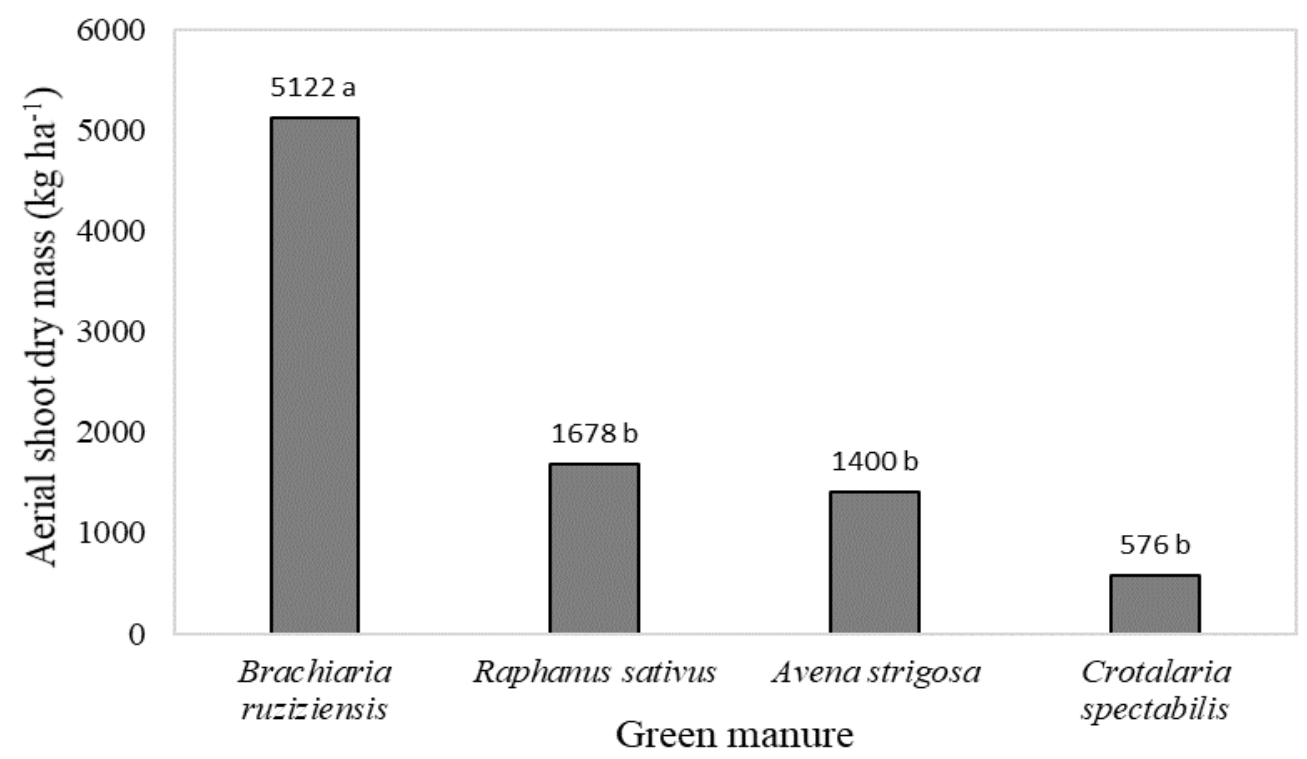

Figure 1. Green manures aerial dry mass productivity $\left(\mathrm{kg} \mathrm{ha}^{-1}\right)$

Figure 2 shows the yield found in $\mathrm{kg} \mathrm{ha}^{-1}$ of maize, cultivated in consortium with the different green manures used in this work. The control treatment presented the highest yield $(2,893 \mathrm{~kg}$ $\mathrm{ha}^{-1}$ ), not differing statistically from corn intercropped with Crotalaria spectabilis. However, these yields were much lower than the average yield of previous years for out-of-season corn, which was $5485 \mathrm{~kg} \mathrm{ha}^{-1}$ (CONAB, 2018).

The low yields found (Figure 2) were due to adverse weather-related phenomena (frost and drought), which can be verified by the data presented in Figures 3 and 4.

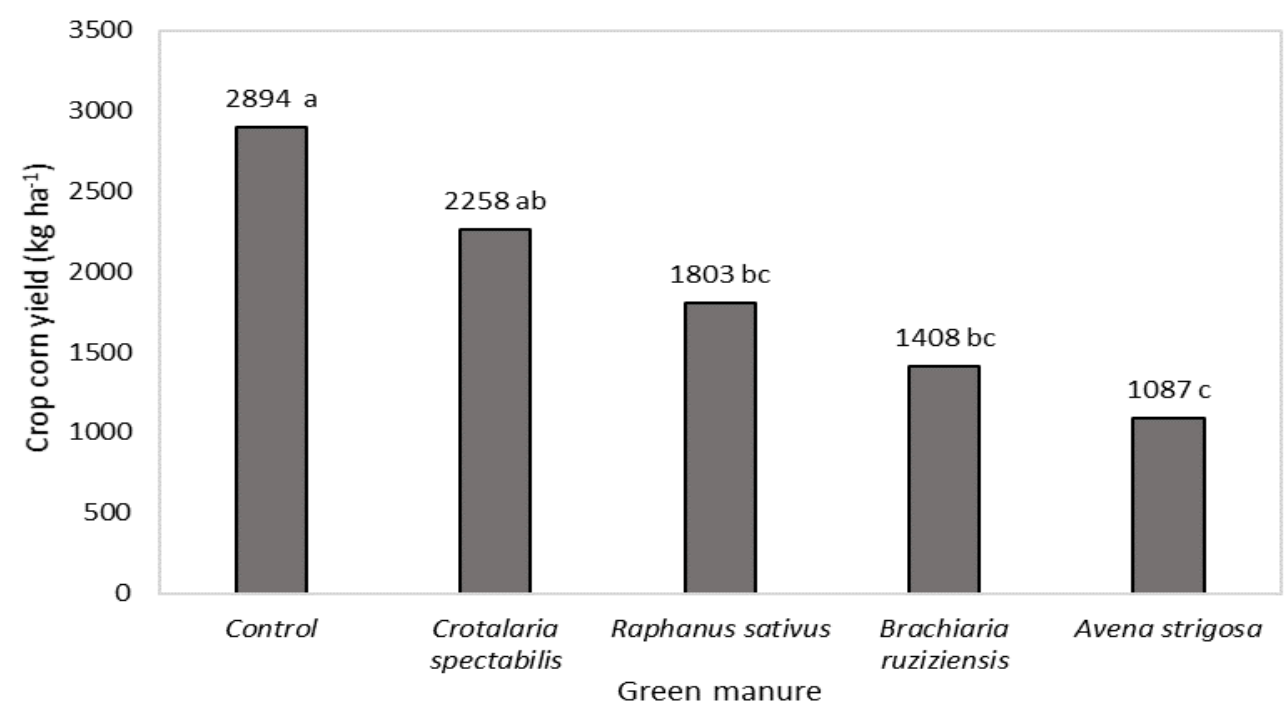

Figure 2. Out-of-season corn yield in intercrop system with green manure ( $\left.\mathrm{kg} \mathrm{ha}^{-1}\right)$

*Means followed by the distinct letters differ significantly from each other at $5 \%$ level of significance. 


\section{Macrothink}

The field data were complemented by information from the INMET (2017), which was accompanied by the weather station of Maringá, Paraná, Brazil. These data presented in Figure 3 , show the daily maximum and minimum temperature. Thus, it can be observed that the temperature drops allowed the formation of frost, which in turn, impaired the productivity of out-of-season corn yield in intercrop system with green manure corn used in this work.

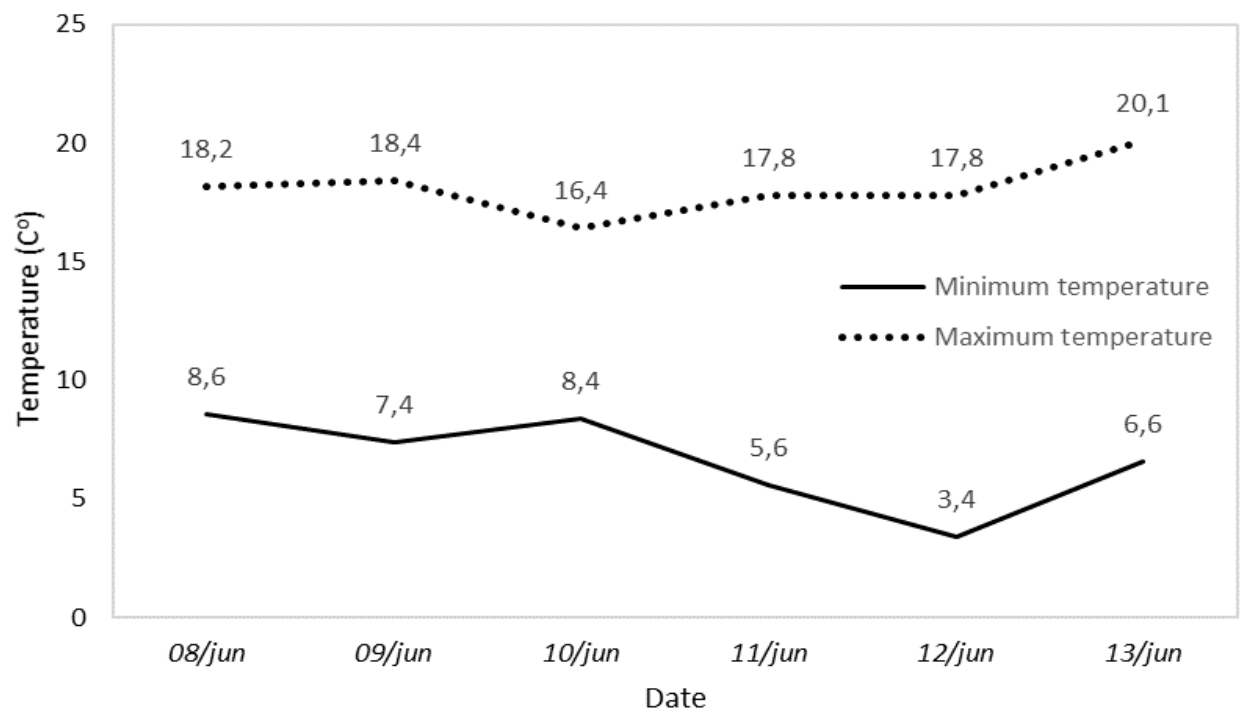

Figure 3. Maximum and minimum temperature data for the period from 06 to 13 June 2016

Figure 4 shows the average precipitation in the region of the Maringá Weather Station, which shows an ideal rainfall for planting corn. However, during the crop development period, this volume fell dramatically, thus causing the crop productivity to be significantly compromised, as obtaining all nutrients depends on the soil water availability (Dourado Neto et al., 2015).

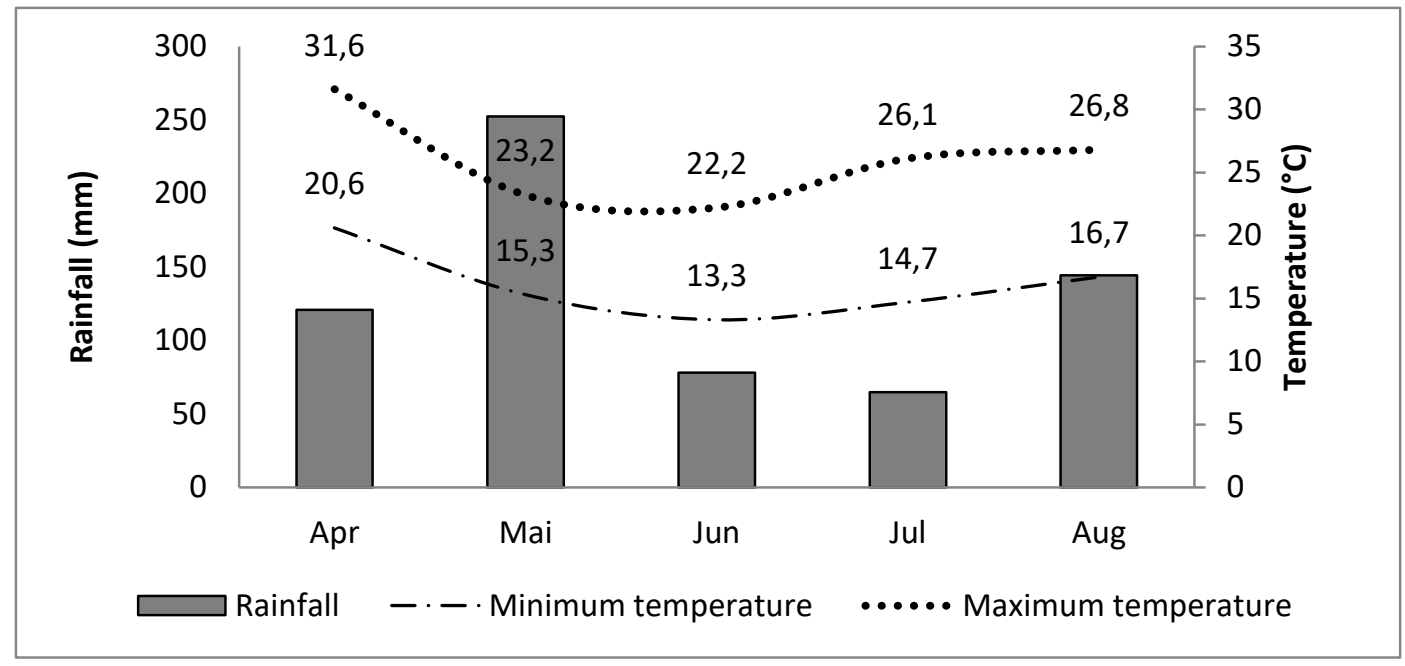

Figure 4. Average monthly rainfall from April to August 2016

Table 1 shows that among all the treatments performed, Treatment 1 (Corn intercropped with 
Brachiaria ruziziensis) stood out among the others, presenting higher soybean plant height, reaching $118.65 \mathrm{~cm}$. This result is explained by the soil decompression effect of the large and aggressive brachiaria root system (Barducci et al., 2009). This decompression allows soybean crop to obtain better conditions for water and nutrient absorption than the conditions presented by the other treatments. In addition to the fact that brachiaria also provides considerably higher biomass than other green manures used. Complementing with Monquero et al. (2010) who obtained information regarding B. ruziziensis mulching, in which soybean presented an increase in biomass in all treatments, since the disposition of mulch on the soil may favor water retention and decrease soil temperature, helping in the development of the crop. However, Carvalho et al. (2004), when cultivating soybean after green manure did not show differences in soybean plant height.

It is still possible to verify that, in terms of stem thickness, soybean crop does not show significant differences among treatments, which may have been provided by cultivar genetics, because even under favorable conditions it does not have significant changes in stem development.

Table 1. Plant height and stem thickness results of soybean crop grown after maize intercropped with green manure

\begin{tabular}{llll}
\hline Treatments & Plant height $(\mathrm{cm})$ & Stem thickness $(\mathrm{mm})$ \\
\hline Brachiaria ruziziensis & $118.65 \mathrm{a}$ & $9.3040 \mathrm{a}$ \\
Crotalaria spectabilis & 96.10 & $\mathrm{~b}$ & $7.9914 \mathrm{a}$ \\
Raphanus sativus & 96.00 & $\mathrm{~b}$ & $7.7474 \mathrm{a}$ \\
Avena strigosa & 92.95 & $\mathrm{~b}$ & $7.5786 \mathrm{a}$ \\
Control & 93.20 & $\mathrm{~b}$ & $7.2162 \mathrm{a}$ \\
\hline Coefficient of variation & $6.89 \%$ & & $13.56 \%$ \\
\hline
\end{tabular}

Means followed by distinct letters in the column differ by $5 \%$ by Tukey test

Table 2 evaluated the number of pods, the weight of 1000 grains and yield per hectare. It was observed that the number of pods is significantly different among treatments, and when used on the brachiaria straw results in higher numbers with 99.95 pods per plant, This is complemented by the result presented earlier in Table 1, which demonstrated that, in the treatment with brachiaria, the highest results of plant height, and consequently larger plants, lead to more substantial number of pods per plant. In a study conducted by Carvalho et al. (2004), the different green manures used did not influence the number of pods in the soybean crop. 
When analyzing the weight of 1000 grains, there was no significant effect of the different green manures used, contrary to the data obtained by Caetano et al. (2018), who found a positive effect of the mulching of winter cover crops on the weight of 1000 soybeans.

On the other hand, it is necessary to point out that in the productivity variable in $\mathrm{kg} \mathrm{ha}^{-1}$ the treatments that differ most are those cultivated on the brachiaria and Crotalaria spectabilis straw, this is due to the fact that the plant, when presenting a height higher height and number of pods in relation to the others, will result in higher productive numbers. In the case of Crotalaria straw cultivation, which has yield levels as optimal as brachiaria, this can be fostered by properties that Crotalaria brings to the soil. Since it can soften the nematode population in the soil (Debiasi et al., 2016) and, above all, provide nitrogen fixation (Castro and Devide, 2018), which will be widely used for soybean cultivation.

Table 2. Pod number, 1000 grain weight and soybean yield results after out-of-season corn intercropped with green manure

\begin{tabular}{|c|c|c|c|c|c|}
\hline Treatments & \multicolumn{2}{|l|}{ Pod number } & 1000 grain weight $(\mathrm{g})$ & \multicolumn{2}{|c|}{$\begin{array}{l}\text { Soybean yield (kg } \\
\left.\mathrm{ha}^{-1}\right)\end{array}$} \\
\hline $\begin{array}{l}\text { Brachiaria } \\
\text { ruziziensis }\end{array}$ & $99.95 \mathrm{a}$ & & $161.00 \mathrm{a}$ & 5,2036 & $\mathrm{a}$ \\
\hline $\begin{array}{l}\text { Crotalaria } \\
\text { spectabilis }\end{array}$ & 59.45 & $\mathrm{~b}$ & $164.00 \mathrm{a}$ & 5,0438 & $\mathrm{a}$ \\
\hline Raphanus sativus & 60.35 & $\mathrm{~b}$ & $164.00 \mathrm{a}$ & 4,8682 & $a b$ \\
\hline Avena strigosa & 61.55 & $b$ & $167.00 \mathrm{a}$ & 4,8358 & $a b$ \\
\hline Control & 60.45 & $b$ & $164.00 \mathrm{a}$ & 4,2118 & $\mathrm{~b}$ \\
\hline $\begin{array}{l}\text { Coefficient of } \\
\text { variation }\end{array}$ & $21.39 \%$ & & $2.93 \%$ & $7.95 \%$ & \\
\hline
\end{tabular}

Means followed by distinct letters in the column differ by $5 \%$ by Tukey test

\section{Conclusion}

The intercropping of out-of-season corn and Brachiaria ruziziensis and Crotalaria spectabilis green manures provided an increase in the productivity of soybean cultivated after single out-of-season corn (control), indicating the positive effect of organic matter produced by these fertilizers, as well as the probable effect of interference of their root systems on the ground. However, according to the data obtained, Raphanus sativus and Avena strigosa, besides not promoting an increase in soybean yield, interfered negatively in corn yield, reaching a loss of $63 \%$ in corn yield when intercropped with Avena strigosa. 


\section{References}

Alvarenga, R. C., Costa, L.,M., Moura, F. W., \& Regazzi, A. J. (1995). Características de alguns adubos verdes de interesse para a conservação e recuperação de solos. Pesquisa Agropecuária Brasileira, 30(2). 175-185.

Barducci, R. S., Costa, C., Crusciol, C. A. C., Borghi, E., Putarov, T. C., \& Sarti, L. M. N. (2009). Produção de brachiaria brizantha e panicum maximum com milho e adubação nitrogenada. Archivos de Zootecnia, 58(222), 211-222. https://doi.org/10.4321/S0004-05922009000200006

Batista, K., Duarte, A. P., Ceccon, G., Maria, I. C., \& Cantarella, H. (2011). Acúmulo de matéria seca e de nutrientes em forrageiras consorciadas com milho safrinha em função da adubação nitrogenada. Pesquisa Agropecuária Brasileira, 46(10), 1154-1160. https://doi.org/10.1590/S0100-204X2011001000006

Caetano, J. H. S., Anschau, K. A., Seidel, E. P., Rosset, J. S., \& Mottin, M. C. (2018). Produtividade da soja em sucessão a plantas de cobertura. In: XII Reunião Sul Brasileira de Ciência do Solo, Xanxerê. Anais XII Reunião Sul Brasileira de Ciência do Solo. http://www.sbcs-nrs.org.br/rsbcs/anais/?secao=trabalhos

Carvalho, M. A. C. et al. (2004). Soja em sucessão a adubos verdes no sistema de plantio direto e convencional em solo de Cerrado. Pesquisa Agropecuária Brasileira, 39(11), 1141-1148. https://doi.org/10.1590/S0100-204X2004001100013

Castro, C. M., \& Devide, A. C. P. (2018). Plantas de cobertura e manejo de aléias no plantio direto de brócolis. Revista Cultura Agronomica, 27, 471-481. https://doi.org/10.32929/2446-8355.2018v27n4p471-481

CONAB. (2018). Indicadores da Agropecuária 12, [Online] Available: < https://www.conab.gov.br/info-agro/precos/revista-indicadores-da-agropecuaria> . (July, 2019).

Dall'Agnol, A., Lazarotto, J. J., \& Hirakuri, M. H. (2010). Desenvolvimento, mercado e rentabilidade da soja brasileira. EMBRAPA, Circular Técnica, 74, p. 20.

Debiasi, H., Franchini, J. C., Dias, W. P., Ramos Junior, E. U., \& Balbinot Junior, A. A. (2016). Práticas culturais na entressafra da soja para o controle de Pratylenchus brachyurus. $\begin{array}{llll}\text { Pesquisa Agropecuária } & \text { Brasileira, } & \text { 51(10), } & \text { 1720-1728. }\end{array}$ https://doi.org/10.1590/s0100-204x2016001000003

Dourado, N. D., Jong Van Lier, Q., Reichardt, K., \& Rodrigues, M. A. T. (2015). Irrigação deve maximizar eficiência no uso da água para garantir produtividade. Visão Agrícola, 13, 66-72. https://www.esalq.usp.br/visaoagricola/edicoes/milho

Ferreira, D. F. (2014). Sisvar: a Guide for its Bootstrap procedures in multiple comparisons. Ciência e agrotecnologia. 38(2), 109-112.

https://doi.org/10.1590/S1413-70542014000200001

Garcia, C. M. P., Andreotti, M., Teixeira Filho, M. C. M., Buzetti, S., Celestrino, T. S., \& Lopes, K. S. M. (2013). Desempenho agronômico da cultura do milho e espécies forrageiras em sistema de Integração Lavoura-Pecuária no Cerrado. Ciência Rural, 43(4), 589-595. 


\section{Macrothink}

https://doi.org/10.1590/S0103-84782013000400005

INMET, (2017). Banco de Dados Meteorológicos para Ensino e Pesquisa. [Online] Available: http://www.inmet.gov.br/portal/index.php?r=bdmep/bdmep (October, 2017).

Monquero, P. A., Milan, B., Silva, P. V., \& Hirata, A. C. S. (2010). Intervalo de dessecação de espécies de cobertura do solo antecedendo a semeadura da soja. Planta Daninha, 28(3), 561-573. https://doi.org/10.1590/S0100-83582010000300013

Oliveira, I. P., Rosa, S. R. A., Kluthcouski, J., Aidar, H., \& Costa, J. L. (2001). Palhada no Sistema Santa Fé. Informações Agronômicas, 93, 6-9.

Rodrigues, G. B., Sa, M. E., Valério Filho, W. V., Buzetti, S., Bertolin, D. C., \& Pina, T. P. (2012). Matéria e nutrientes da parte aérea de adubos verdes em cultivos exclusivo e consorciado. Revista Ceres, 59(3), 380-385.

https://doi.org/10.1590/S0034-737X2012000300013

Souza, J. P., \& Macedo, M. A. S. (2007). Análise de viabilidade agroeconômica de sistemas orgânicos de produção consorciada. Associação Brasileira de Custos, 2(1), 57-78. Avaiable on: https://abcustos.emnuvens.com.br/abcustos/article/view/14

\section{Copyright Disclaimer}

Copyright for this article is retained by the author(s), with first publication rights granted to the journal.

This is an open-access article distributed under the terms and conditions of the Creative Commons Attribution license (http://creativecommons.org/licenses/by/4.0/). 